\title{
Land Certification Information System of Sidoarjo Regency Land Office
}

\section{Rancang Bangun Sistem Informasi Sertifikasi Tanah Kantor Pertanahan Kabupaten Sidoarjo}

\author{
Rizky Fajar Ryandi ${ }^{1}$, Yulian Findawati ${ }^{2}$ \\ \{141080200038@umsida.ac.id ${ }^{1}$, yulianfindawati@umsida.ac.id² $\}$
}

Program Studi Informatika, Fakultas Sains dan Teknologi, Universitas Muhammadiyah Sidoarjo

\begin{abstract}
The purpose of this research is to build land certification information system of Sidoarjo Regency Land Office. The information system is a form of development in making it easier for prospective applicants to make land easier and faster. To support the performance of employees of the Sidoarjo Regency Land Office and facilitate users in the manufacture of land certificates. In this research the method used is software development life cycle. The stage cycle contains requirement definition, system and software design, implementation and unit testing, intergration and system testing, operation and maintenance so that the implementation can be maximized. The result of this research has been built an information system based on Land Certification that greatly facilitates the performance of employees of the Sidoarjo Regency Land Office. Conclusion of research and discussion that Land Certification information system runs well and smoothly. With the land information system is expected to help the work of officers of the office of the national land agency, so that the efficiency and effectiveness of service performance can be improved and accelerate the service of officers to land-making transactions in Sidoarjo Regency. Respondents to the trial there were 3 people of Sidoarjo Regency and 7 officers of the Sidoarjo Regency Land Office. Data collection methods are carried out with interviews, literature studies and questionnaires. Based on the results of soil certification information system analysis, some aspects of PIECES analysis have obtained quite good results. One of them can be seen from the results of service category analysis, where the overall percentage of test questionnaires that have been shared, on average fall into the range of the category "Very Easy". The percentage of eligibility obtains a percentage of 100\%. Thus it can be concluded that the information system has good quality and is very feasible for the process of processing land certification data.
\end{abstract}

Keywords - System; Information; Land; Land Certification

\begin{abstract}
Abstrak. Tujuan penelitian ini adalah membangun Sistem Informasi Sertifikasi Tanah Kantor Pertanahan Kabupaten Sidoarjo. Sistem informasi tersebut sebagai bentuk pengembangan dalam mempermudah calon pemohon pembuatan tanah agar lebih mudah dan cepat. Untuk menunjang kinerja pegawai Kantor Pertanahan Kabupaten Sidoarjo dan memudahkan pengguna dalam pembuatan sertifikat tanah. Dalam penelitian ini metode yang digunakan adalah software development life cycle. Adapun siklus tahapannya berisi requirement definition, system and software design, implementation and unit testing, intergration and system testing, operation and maintenance sehingga pelaksanaan yang akan dilakukan dapat maksimal. Hasil dari penelitian ini telah dibangun sistem informasi berbasis Sertifikasi Tanah yang sangat memudahkan kinerja petugas pegawai Kantor Pertanahan Kabupaten Sidoarjo. Kesimpulan dari penelitian dan pembahasan bahwa sistem informasi Sertifikasi Tanah berjalan dengan baik dan lancar. Dengan adanya sistem informasi pertanahan diharapkan dapat membantu pekerjaan petugas kantor badan pertanahan nasional, sehingga efisiensi dan efektivitas kinerja pelayanan dapat ditingkatkan serta mempercepat pelayanan petugas terhadap transaksi pembuatan tanah di Kabupaten Sidoarjo. Responden uji coba ada 3 masyarakat Kabupaten Sidoarjo dan 7 petugas Kantor Pertanahan Kabupaten Sidoarjo. Metode pengumpulan data dilakukan dengan wawancara, studi pustaka dan kuesioner. Berdasarkan hasil analisis Sistem Informasi Sertifikasi Tanah yaitu beberapa aspek analisis PIECES sudah memperoleh hasil yang cukup baik. Salah satunya dapat dilihat dari hasil analisis kategori service, dimana presentase keseluruhan angket uji yang telah dibagikan, rata-rata masuk dalam range kategori 'Sangat Mudah". Presentase kelayakan memperoleh presentase sebesar 100\%. Dengan demikian dapat disimpulkan bahwa sistem informasi memiliki kualitas baik dan sangat layak untuk proses pengolahan data sertifikasi tanah.
\end{abstract}

Kata kunci - Sistem; informasi; Pertanahan; Sertifikasi Tanah

\section{Pendahuluan}

Dewasa ini, perkembangan teknologi telah berjalan begitu cepat, sehingga pengiriman dan penerimaan informasi oleh publik menjadi lebih singkat dan efektif. Disamping itu juga kepemilikan aset juga sangat penting untuk kelangsungan hidup yang akan datang. Aset tanah merupakan aset yang bernilai paling tinggi, karena setiap tahun 
selalu mengalami kenaikan. Selain itu tanah dapat dijadikan sebagai tempat dalam bidang pertanian, gedung, pemukiman, perdagangan dan lain-lain [1].

Menurut Warren, dkk (2016), yang termasuk dalam aset tetap atau biasa disebut aset jangka panjang maupun secara general bersifat permanen meliputi alat-alat, mesin, gedung, serta tanah. Penjabaran lain mengenai aset tetap juga mencakup aset peralatan, pabrik, serta bangunan. Terdapat aspek spesifik yang melekat dalam aset tetap yang mana aset tersebut memiliki wujud serta memiliki kemampuan untuk dioperasikan oleh perusahaan secara normal, serta tidak dijadikan penawaran penjualan yang termasuk dalam operasi secara umum.

Masing-masing individu saat ini berusaha untuk menjadi pemilik dan penguasa tanah yang dilatarbelakangi oleh meningkatnya persentase penduduk per tahun yang tidak di dukung oleh meningkatnya kesediaan tanah pula (Ismaniar Ismail,2013). Melalui Intruksi Presiden RI No. 2 Tahun 2018, terdapat usulan layanan penciptaan sertifikasi tanah bersistem secara keseluruhan di area negara Indonesia. Pemerintah merancang program percepatan registrasi tanah via pendaftaran tanah bersistem lengkap hingga periode 2025 atas tervalidasinya keseluruhan area tanah yang ada di Indonesia mengacu pada himbauan di Pasal 19 Undang-Undang Nomor 5 Tahun 1960 mengenai Peraturan Dasar Pokok-Pokok Agraria. Untuk mendapatkan tanah yang tersertifikasi, masyarakat dapat menjalankan tahapan sesuai anjuran yang dimuat dalam Peraturan Kepala Badan Pertanahan Nasional Republik Indonesia Nomor 1 tahun 2010 yang mana harus melalui loket pelayanan Kantor Pertahanan untuk mendapatkan izin sertifikasi tanah atas pemohon.

Selanjutnya, syarat-syarat diajukannya sertifikasi tanah akan diperiksa dan divalidasi oleh petugas loket. Apabila seluruh syarat dianggap valid dan sesuai, akan petugas loket kemudian mencatat dalam buku registrasi dengan cara manual. Pembayaran untuk pengukuran dapat dibayarkan oleh pemohon setelah tahap tersebut. Dalam menjalankan tahap pengukuran, pemohon beserta petugas terakit wajib datang di area yang didaftarkan. Langkah berikutnya, untuk mendapatkan inspeksi tanah di lapangan, pemohon membayar pada Panitia A. Tanah akan ditinjau langsung oleh Panitia A di lapangan. Pemohon bisa melakukan registrasi atas SK Hak setelah dilakukan pemeriksaan dengan biaya Rp. 50.000,- mengacu pada PP No., 13 Tahun 2010. akan dikeluarkan dengan dibubuhi tanda tangan kepala kantor pasca refistrasi SK Hak, yang siap diserahkan kepada pemohon [2].

Sistem Informasi Pembuatan Tanah adalah sistem yang bisa mempermudah aktivitas pendaftaran sertifikasi tanah yang mana membuat lembaga menerima data mengenai jumlah sertifikasi yang telah dibuat dalam jangka waktu yang ditentukan [3].

Sistem Informasi Pembuatan Tanah ini dimaksudkan supaya kinerja instansi terkait dapat meningkat melalui kegiatan sertifikasi tanah. Peneliti berencana untuk membuat sistem yang memberikan kemudahan registrasi pembuatan tanah di Kabupaten Sidoarjo dengan sistem yang lebih mudah [4].

\section{METODE}

\section{A. Flowchart}

Merupakan komponen dari arahan yang memuat deskripsi atas tahapan yang terkandung di sebuah program maupun masalah. Flowchart berguna untuk menyederhanakan pengerjaan suatu masalah terutama masalah yang membutuhkan pemahaman dan analisis lebih dalam. Flowchart adalah jenis deskripsi yang berisikan diagram alir yang searah maupun dua arah dengan umpan balik. Flowchart berfungsi dalam membangun program yang dirancang sebagai tahapan merangkai program [5].

\section{B. Data flow diagram}

Rosa, dan M. Shalahuddin (2016:70) menjelaskan bila dfd berguna dalam menyajikan suatu sistem maupun software dalam level yang lebih terperinci untuk menyajikan alur data dan peran yang lebih jelas lagi [6].

\section{Antarmuka (interface)}

Merupakan bagian dari servis yang tersedia pada sistem operasi dengan peran menjembatani hubungan yang melibatkan sistem operasi dengan user. Antarmuka merupakan aspek dari sistem operasi yang memiliki kontak dengan user secara langsung [7].

\section{Bahasa pemrograman PHP}

Menurut Maimunah (2017:2) Hypertext Preprocessor atau biasa disebut PHP merupakan istilah pemrograman web server-side dengan karaktestik open source. PHP tergolong dalam script yang terhubung pada HTML yang dimuat dalam server (server side HTML embeded scripting). PHP merupakan script yang diperlukan dalam merancang page pada website secara dinamis. Dinamis merujuk pada tampilan halaman yang dirancang sesuai permintaan pengguna. Operasi ini membuat data yang direquest oleh pengguna selalu diperbarui. Seluruh script diolah di masing-masing server yang memuat server tersebut [8].

\section{E. Database}

Yanto (2016:11) berpendapat bahwa database adalah himpunan data yang memiliki relevansi yang disimpan bersamaan dengan terstruktur tanpa adanya redudansi dengan tujuan pemenuhan keperluan penggunanya. Di sisi lain, Lubis (2016:3) berpendapat bahwa database adalah pusat himpunan data yang memiliki keterkaitan dengan wadah 
suatu organisasi dengan tujuan memberikan kemudahan dan mempersingkat waktu penggunaan data tersebut saat dibutuhkan kembali [9].

\section{F. MySQL}

Kadir (dalam Ruhul Amin 2017:115) berpendapat bahwa MySQL merupakan perangkat lunak yang berjenis server data basis dan memiliki karakteristik open-source. Di sisi lain, Saputra dan Agustin (dalam Hinsa dan Ahmad Ishag 2016:65) menganggap MySQL tidak tergolong dalam jenis bahasa pemrograman. MySQL adalah jenis database yang digemari secara global. MySQL memanfaatkan SQL Language (Structure Query Language) dalam menjalankan kerjanya. Maka dapat disebut bahwa dunia mengacu pada standar MySQL dalam prosedur basis data bagi olah data. Menurut penjelasan sebelumnya, dapat ditarik kesimpulan bahwa MySQL termasuk model data terhubung dengan karakteristik open-source yang secara standar memiliki penggunaan global.[10].

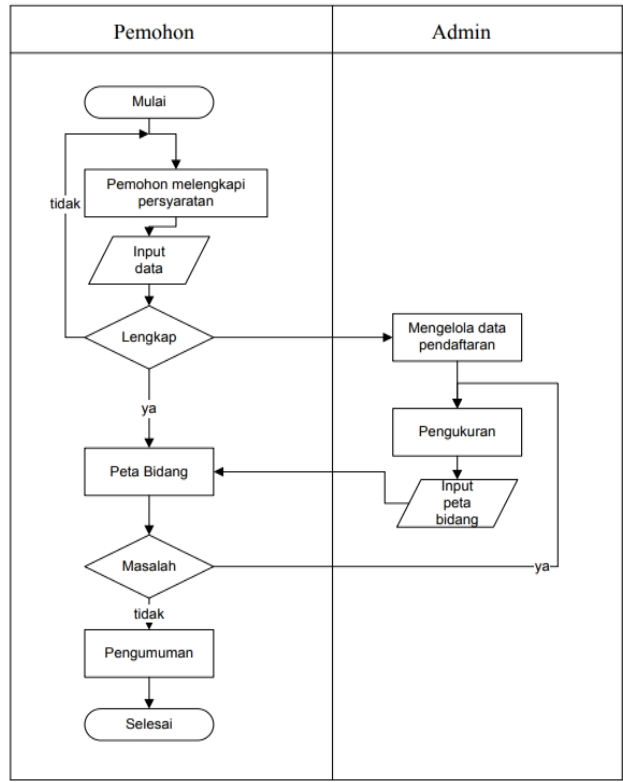

Gambar 1. Flowchart Pembuatan Sistem Informasi sertifikasi Tanah

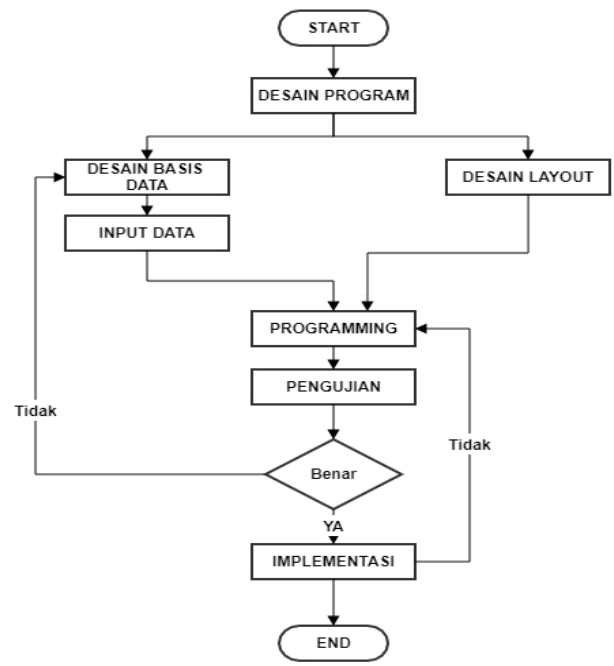

Gambar 2. Flowchart Inplementasi Sistem Informasi Sertifikasi Tanah 
Procedia of Engineering and Life Science Vol.1 No. 1 March 2021

Seminar Nasional \& Call for Paper Fakultas Sains dan Teknologi (SENASAINS $1^{\text {st }}$ )

Universitas Muhammadiyah Sidoarjo

Data flow diagram

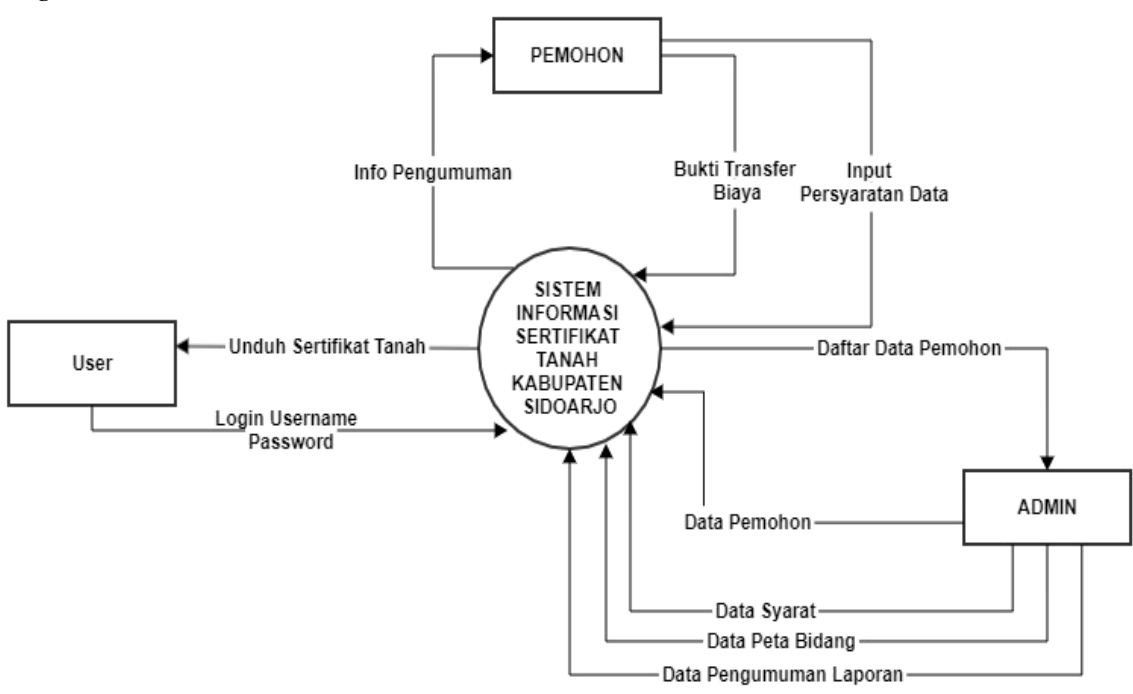

Gambar 3. Data Flow Diagram Sistem

Dapat diamati melalui penyajian Flow Diagram pada Gambar. 3 sebagai bentuk Sistem Informasi Sertifikasi Tanah di Kantor Pertahanan Kabupaten Sidoarjo.

a. Rancangan penyajian antarmuka dalam aplikasi Sistem Informasi Sertifikat Tanah diklasifikasikan atas dua bagian meliputi halaman aplikasi yang ditujukan untuk pengguna serta halaman aplikasi yang ditujukan untuk pengelola (admin).

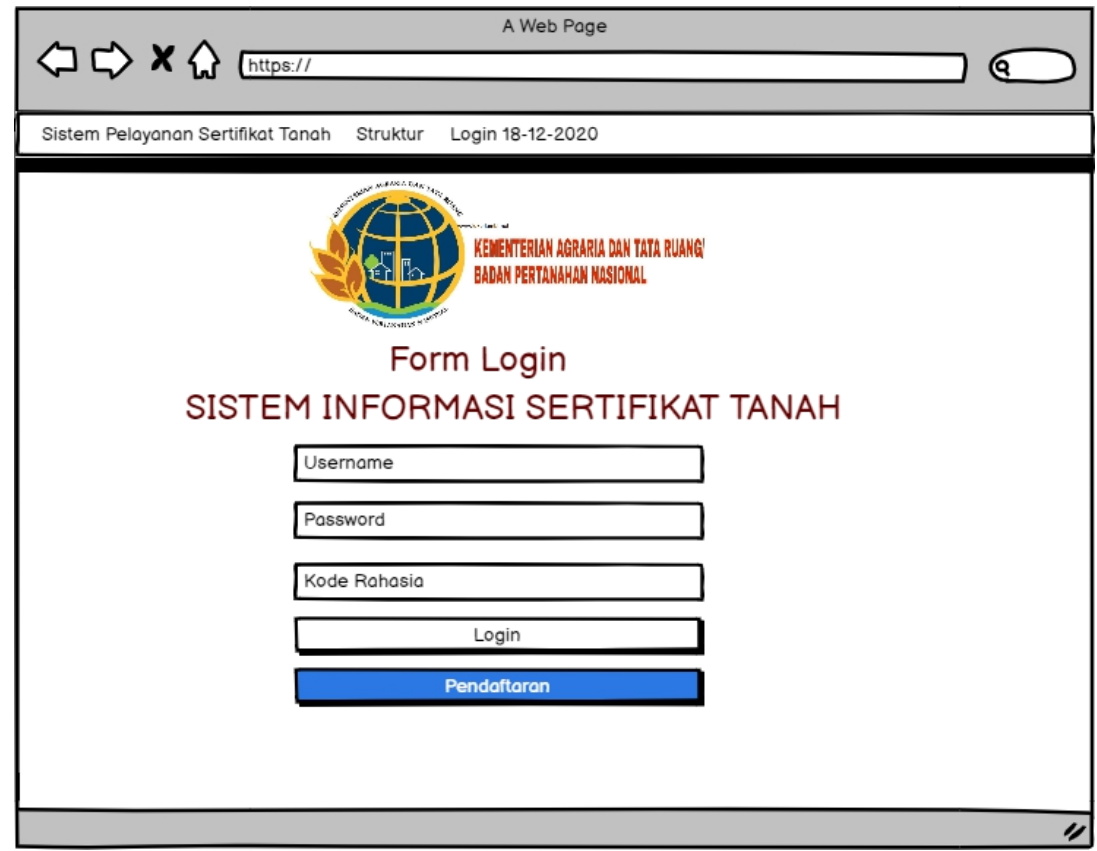

Gambar 4. Halaman Utama User 
Procedia of Engineering and Life Science Vol.1 No. 1 March 2021

Seminar Nasional \& Call for Paper Fakultas Sains dan Teknologi (SENASAINS $1^{\text {st }}$ )

Universitas Muhammadiyah Sidoarjo

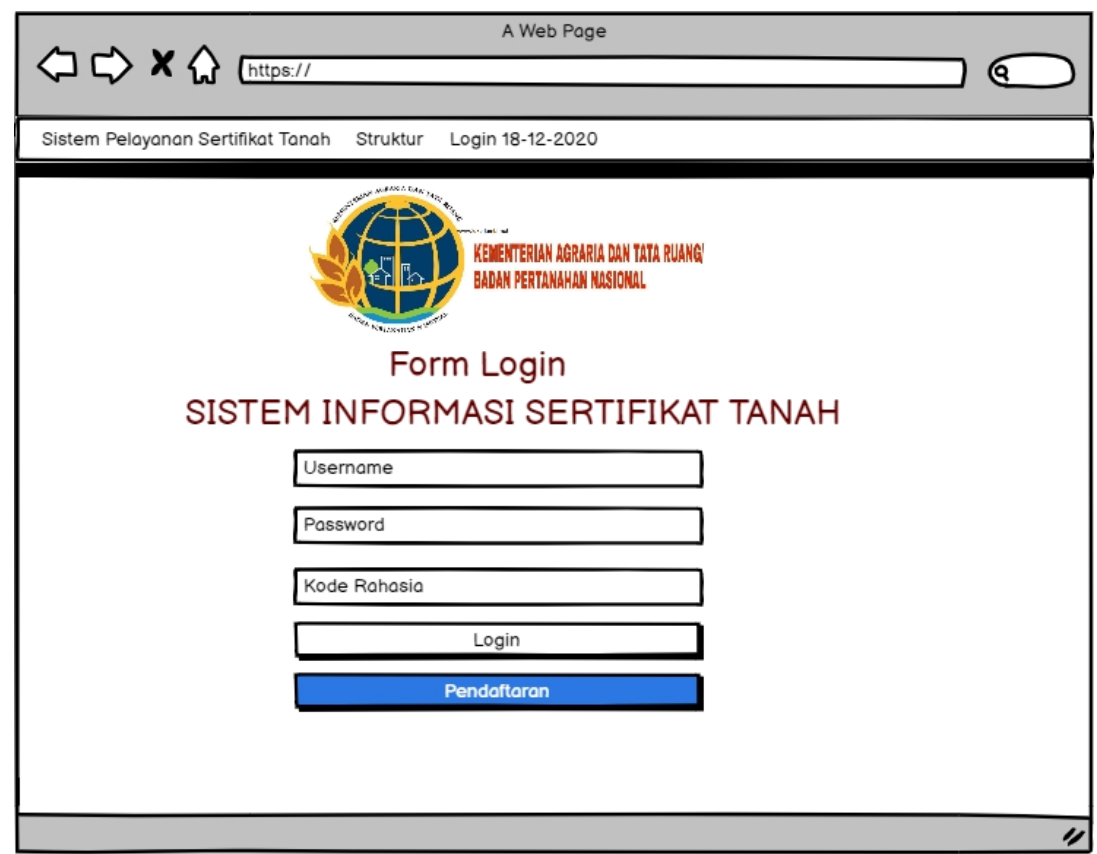

Gambar 5. Halaman Utama Admin

\section{Hasil dan Pembahasan}

Berikut ini merupakan hasil dari tahapan penyusunan yang dibahas dalam bab sebelumnya mengenai sistem:

1. Fitur-fitur fungsional yang disediakan oleh pengguna adalah fitur melakukan pendaftaran tanah dengan melengkapi syarat data.

2. Disediakan oleh admin adalah fitur melihat data pendaftaran tanah, mengelola data petugas dan pengumuman tanah sudah jadi.

3. Sistem ini pemohon dapat melakukan pendaftaran pembuatan sertfikat tanah dengan menginputkan data yang diperlukan.

4. Tanpa harus datang ke kantor langsung, yang sangat lama dalam menunggu antrian.

5. Hasil dari sistem informasi pertanahan ini, dapat diunduh langsung lewat sistem.

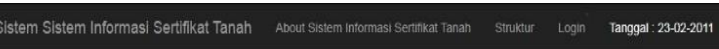

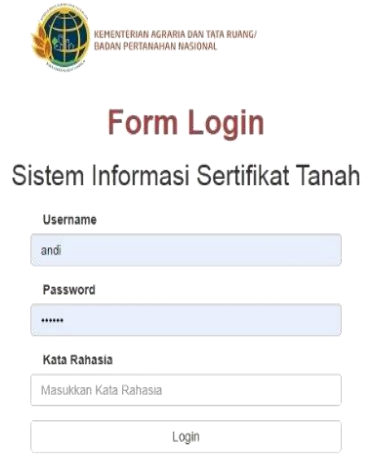

Gambar 6. Halaman Login 
Procedia of Engineering and Life Science Vol.1 No. 1 March 2021

Seminar Nasional \& Call for Paper Fakultas Sains dan Teknologi (SENASAINS $1^{\text {st }}$ )

Universitas Muhammadiyah Sidoarjo

Home Ajukan Pemohonan Permohonan Saja Logout

Selamat Datang Karmin di Sistem Informas

Sertifikat Tanah

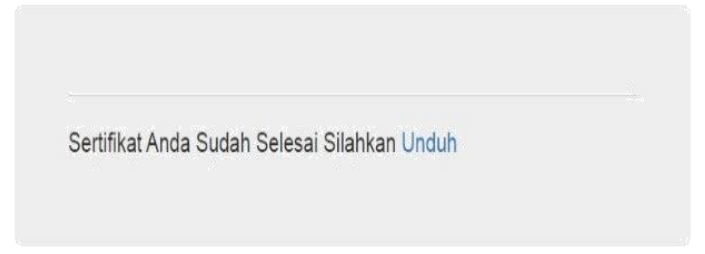

Ocopyright Rizlyy Fajar Ryand

Gambar 7. Halaman Utama Admin

Home Autkan Permohonan Pemolonan Saya Logout

Daftar Pemohon

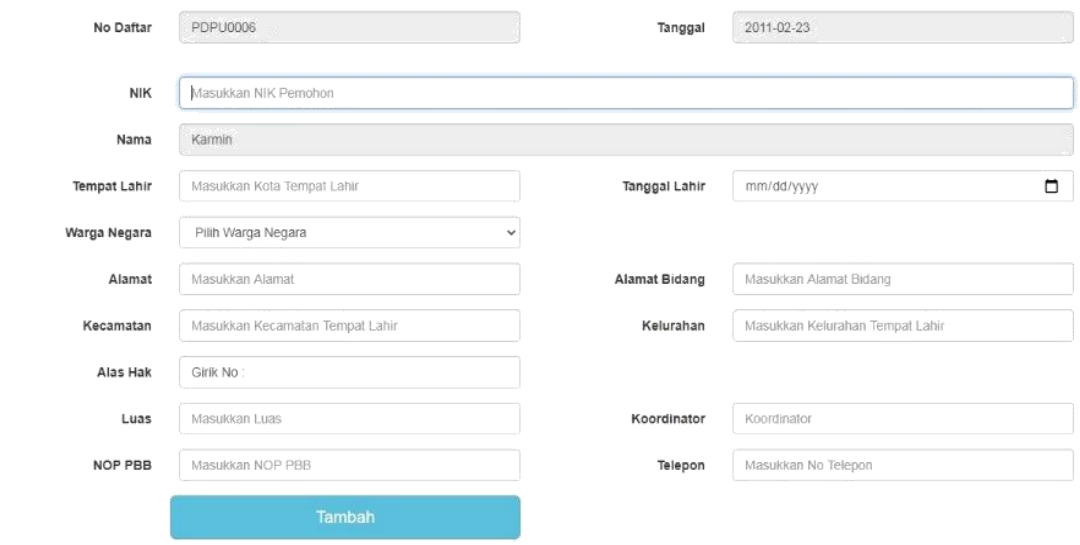

(i) copyright Rizky Falar Ryandi

Gambar 8. Halaman Daftar Pemohon 


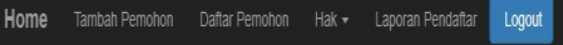

\begin{tabular}{|c|c|c|c|c|c|c|c|c|}
\hline \multicolumn{6}{|c|}{ Data Pendaftar } & \multicolumn{3}{|c|}{ Cari Nana Pendater } \\
\hline No & No Daftar & Tanggal Daftar & Nama & Biaya & Status Bayar & Aksi & & \\
\hline 1 & PDPUOOO1 & 2018-07-23 & santo & Rp.5000000 & Betum Bayjar & Update & Cetak & Hapus \\
\hline 2 & PDPUOOO2 & $2020-11-22$ & Karmin & Rp.5000000 & Sucah Bajar & Update & Cetak & Hapls \\
\hline 3 & PDPUOOOS & $2020-11-22$ & Karmin & Rpp5000000 & Belum Bayar & Update & Cetata & Hapls \\
\hline 4 & PDPUOOO4 & $2020-11222$ & Karmin & Rp.5000000 & Belum Bayar & Upate & Cetak & Hapls \\
\hline 5 & PDPUOOOS & $2020-11-25$ & mimi peri & Rp.5000000 & Betum Bayar & Update & Cetak & Hapus \\
\hline
\end{tabular}

Gambar 9. Halaman Data Pendaftar

Pengujian sistem menggunakan black box testing

Black box testing akan melakukan percobaan melalui observasi atas hasil menguji dengan melakukan pengamatan dari hasil demo dengan memanfaatkan data uji serta pengecekan fungsi software.

Tabel 1. Uji BlackBox Testing Halaman Login User

\begin{tabular}{cllc}
\hline No & \multicolumn{1}{c}{ Skenario Pengujian } & \multicolumn{1}{c}{ Hasil yang diharapkan } & Kesimpulan \\
\hline 1 & $\begin{array}{l}\text { Jika } \text { username dan password } \\
\text { tidak diisi, kemudian user } \\
\text { mengklik tombol login. }\end{array}$ & $\begin{array}{l}\text { Muncul pesan } \\
\text { kesalahan”Data yang anda } \\
\text { masukkan Salah!. }\end{array}$ & Valid \\
& $\begin{array}{c}\text { Mika } \text { username dan password } \\
\text { diisi tetapi salah. }\end{array}$ & $\begin{array}{l}\text { Muncul pesan kesalahan” } \\
\text { Data yang anda masukkan } \\
\text { Salah!. }\end{array}$ & Valid \\
& $\begin{array}{l}\text { Masuk ke menu utama. } \\
\text { dika } \text { username dan password }\end{array}$ & Valid \\
\hline
\end{tabular}

Tabel 2. Uji Black Box Testing Halaman Login Admin

\begin{tabular}{cllc}
\hline No & \multicolumn{1}{c}{ Skenario Pengujian } & \multicolumn{1}{c}{ Hasil yang diharapkan } & Kesimpulan \\
\hline 1 & $\begin{array}{l}\text { Jika } \text { username, password, dan } \\
\text { kode rahasia tidak diisi, } \\
\text { kemudian user mengklik tombol } \\
\text { login. }\end{array}$ & $\begin{array}{l}\text { Muncul pesan } \\
\text { kesalahan’Data yang anda } \\
\text { masukkan Salah!. }\end{array}$ & Valid \\
& & & \\
\hline 2 & Jika username, password, dan & Muncul pesan kesalahan” \\
& kode rahasia diisi tetapi salah. & Data yang anda masukkan \\
& & Salah!. & Valid \\
& Jika username, password, dan & Masuk ke menu utama. & \\
\hline 3 & kode rahasia diisi benar. & & Valid \\
\hline
\end{tabular}




\section{KESIMPULAN}

Telah dibangun Sistem Informasi Sertifikasi Tanah Kantor Pertanahan Kabupaten Sidoarjo, yang dulunya kurang efisien dan antrian menunggu sangat lama. Sekarang dapat disampaikan secara efisien dan data dapat tersimpan lebih spesifik. Fitur Sistem Informasi Sertifikasi Tanah Kantor Pertanahan Kabupaten Sidoarjo meliputi data admin, data user, data pemohon, data hak, data bukti. Hasil output berupa laporan data pemohon dan unduh yang sudah jadi. Dengan adanya perancangan Sistem Informasi Sertifikasi Tanah Kantor Pertanahan Kabupaten Sidoarjo ini dapat memudahkan dalam pembuatan pertanahan secara cepat dan akurat. Tanpa harus menunggu antrian yang panjang.

\section{UCAPAN TERIMA KASIH}

Dengan demikian, pada kesempatan kali ini izinkan saya sebagai penulis untuk mengahturkan terimakasih dan penghargaan yang sebesar sebesarnya kepada yang terhormat :

1. Ibu Yulian Findawati, ST., M.MT selaku Dosen Pembimbing yang telah memberikan bimbingan, arahan, dan dukungan sehingga skripsi ini dapat terselesaikan dengan baik

2. Bapak Dr. Hidayatulloh, M.Si, selaku Rektor Universitas Muhammadiyah Sidoarjo

3. Bapak Dr. Hindarto, S.Kom., MT, selaku Dekan Fakultas Sains dan Teknologi Universitas Muhammadiyah Sidoarjo

4. Bapak Ir. Sumarno., MM, selaku Kepala Program Studi Informatika Fakultas Sains dan Teknologi

5. Rekan Rekan Informatika A1 yang membantu dalam moral moril serta mental, terlebih memberikan masukan dan inspirasi untuk selesai nya penulisan ini

6. Secara Khusus, Penulis mengungkapkan rasa terimakasih yang tiada tara kepada seluruh keluarga tercinta yang mana telah memberikan bantuan dan dorongan serta seluruh pengertian yang besar kepada kami. Baik itu selama tahap penulisan maapun pembuatan program

Serta kerabat dekat dan rekan rekan seperjuangan yang tak bisa kami tulis satu persatu. Semoga Allah SWT memberikan balasan atas kebaikan yang sesuai dan setimpal.

\section{REFERENSI}

[1] Azhar, Susanto. 2017. Sistem Informasi Akuntansi. Cetakan pertama. Lingga Jaya. Bandung.

[2] Ahira, Anne. 2012. Pengertian Kontribusi.Bandung : Kencana A.S, Rosa, dan M. Shalahuddin. 2016. Rekayasa Perangkat Lunak Terstruktur dan Berorientasi Objek. Bandung: Informatika Bandung.

[3] Agus Saputra dan Feni Agustin. "Pemograman PHP \& MySql ", 1st ed, Jakarta : Kelompok Gramedia, 2017.

[4] Hidayatullah, Priyanto, dan Jauhari Khairul Kawistara. 2017. Pemrograman Web. Bandung: Informatika Bandung.

[5] Hidayatullah, Priyanto dan Jauhari Khairul Kawistara. 2017. Pemrograman Web. Bandung: Informatika.

[6] Kadir, Abdul. 2014. Pengenalan Sistem Informasi Edisi Revisi. Yogyakarta: Andi Offset. Mulyadi. (2016). Sistem informasi Akuntansi. Jakarta: Salemba Empat.

[7] Lubis, Adyanata. 2016. Basis Data Dasar Untuk Mahasiswa Ilmu Komputer. Yogyakarta: CV. Budi Utama.

[8] Mulyadi. (2016). Sistem Informasi Akuntansi. Jakarta: Salemba Empat.

[9] Muslihudin, Muhamad Oktafianto. 2016. Analisis dan perancangan Sistem Informasi Menggunakan Model Terstruktur dan UML. Yogyakarta : Andi

[10] Maimunah, David Ericson Manalu, Dian Budi Kusuma. 2017. Perancangan Prototype Visual Pada Bagian Desain Sebagai Media Informasi dan Promosi pada PT. Sulindafin. Seminar Teknologi Informasi dan Multimedia.

[11] Mulyani, Sri. 2016. Sistem Informasi Manajemen. Bandung: Abdi Sistematika. Diambil:https://books.google.co.id/books?id=k7rPDgAAQBAJ\&printsec=frontcover\&dq=sistem+informasi+ manajemen+rumah+sakit\&hl=id\&sa=X\&ved=0ahUKEwjc_uDy4rVAhVEQo8KHfZPAlkQ6wEIIjAA\#v=one page\&q=sistem\%20informasi\%20manajemen\%20rumah\%20sakit\&f=false [15 April 2017].

[12] O'Brien, A James and George M Marakas., 2016, Analisa Sistem Informasi/Tata Sutabri, Ed 1, Andy, Yogyakarta.

[13] Rosa A. S dan M. Shalahuddin, 2016, Rekayasa Perangkat Lunak (Terstruktur dan Berorientasi Objek). Bandung : Informatika Bandung

[14] Rizky Soetam. 2017. Rekayasa Perangkat Lunak. Malang: Penerbit Seribu Bintang.

[15] Swastika dan Putu Agus. 2016. Audit Sistem Informasi dan Tata Kelola Teknologi Informasi. Yogyakarta : Andi

[16] Sidik, Betha.2014.Pemograman Web dengan PHP, revisi kedua.Bandung:Informatika

[17] Spillane. 2015. „Pengembangan Pariwisata Dalam Konteks Pembangunan Wilayah“. Online dari http://www.radarplanologi.com. Diakses tanggal 12 januari 2017Amin, Ruhul, 2017, Jurnal Rancang Bangun 
Procedia of Engineering and Life Science Vol.1 No. 1 March 2021

Seminar Nasional \& Call for Paper Fakultas Sains dan Teknologi (SENASAINS 1st)

Universitas Muhammadiyah Sidoarjo

Sistem Informasi Penerimaan Siswa Baru pada SMK Budhi Warman 1 Jakarta, Vol. 2 No. 2, Teknik Informatika, STMIK Nusa Mandiri Jakarta.

[18] Tyoso, Jaluanto Sunu Punjul. 2016. Sistem Informasi Manajemen. Ed.1, Cet.1 Yogyakarta : Deepublish, 2016.

[19] Yoeti, Oka. A. 2000. Ekowisata: Pariwisata Berwawasan Lingkungan. Jakarta: PT. PertjaAzhar, Susanto. 2017. Sistem Informasi Akuntansi. Cetakan pertama. Lingga Jaya. Bandung.

[20] Yanto, Robi. 2016. Manajemen Basis Data Menggunakan MySQL. Yogyakarta: Deeppublish. 